\title{
Social Constitutional State as Necessary Institutional form of Legal Freedom
}

\author{
Valentin Yakovlevich Lyubashits ${ }^{1}$ \\ Evgenia Yurevna Kiyashko² \\ Alla Aleksandrovna Timofeeva² \\ ${ }^{1}$ The Southern State University \\ 2 Vladivostok State University Ecomomics and Service \\ kafedra_tgp@mail.ru, evgeniya.kiyashko@vvsu.ru,niko.m_2002@mail.ru
}

\section{Doi:10.5901/mjss.2015.v6n3s6p263}

\begin{abstract}
The author's article analyzes the formation, evolution and modern functioning of the social state as an institutional form of legal freedom. It shows that there are four innovative stages in the legal institutionalization of the modern political supremacy: the civil state, the constitutional state, the democratic constitutional state and the social constitutional state. It is noted that in the process of accumulation, as more experience of social and socially oriented economic policy realization will be gained, the social human rights were institutionalized. Besides, the article proves that spiritual development prerequisites by the constitutional state of the social function were the enlightenment idea of a human right. In turn the standard principle of solidarity also found realization in the social constitutional state principle, meaning the intervention of the state in private citizens' life for their worthy life. This plan includes the modern state responsibility increase in the social and economic sphere that notes the transformation of liberalism and reconsideration the previous principle of non-interference. The article gives also the definition and distinction of such interconnected political and legal phenomena as: "the social constitutional state policy ", its "social and economic policy". The authors argue that with the social function development the constitutional state has become an extremely difficult political association; its purpose is to ensure the conditions for realization and the guarantees of economic, political and social human rights, and the living standards rise of civil society.
\end{abstract}

Keywords: social state, right, human rights, political processes, political and legal evolution.

\section{Introduction}

In scientific literature the constitutional state is the state that ensures the conditions for realization by each person the right for worthy life (Volgin N. A., Gritsenko N. N., Sharkov F.I., 2003). The area of "worthy life" is defined in concepts of living standards, the amount and quality of the vital benefits appropriated by individuals and social groups according to the society or international community cultural standards. There is the minimal level of life that out of which means a hand-to-mouth existence that is unworthy for the person (Kamenetsky VA., Patrikeev V.P., 2001).

The area of human rights on worthy life is called as the social rights, i.e. an opportunity to apply for receiving the material benefits in the conditions of vital risk from the state. In the context of the social rights the vital risk is a situation of damage or loss of vital resources arising not because of individuals' activity, but because of the natural and public processes. The reduction of vital risk is possible at the expense of the compensating measures providing security of people. For example, the risk of accident, illness, unemployment, loss of a breadwinner decreases the charity, social insurance, pensions, grants and other types of help. In jurisprudence, political science and economic sociology this type of security is called "the social security", and the set of measures from the state - "the social policy" (Mamut L.S., 2001; Gritsenko N. N., 1994).

The starting point of the social policy of the constitutional state is individual's care about his of vital risk reduction (Chernobrovkin I.P., 1997). Usually to the right for social security, the right for education, the right for health protection and medical care, the right for housing, the special rights of children and the right of disabled people relate to social human rights. The social policy object of the constitutional state is individuals or groups of individuals, without the relation to of economic status or income. The other feature of the social policy is its continuous character because it is directed to individuals' security. The most obvious example is retirement insurance: its benefit is found through decades after the first contribution. The same relates to life insurance, the credits, etc. 


\section{Literature Review}

The Enlightenment that created a new picture of mankind in which material well-being was referred, according to I. Kant, to the human right "for happy life" in this world relates to intellectual prerequisites of the modern social policy of the constitutional state (Kant I., 1966, p. 374). The belief in possibility of happiness (due to progress of the human reason embodied in material living conditions) was combined with the thesis about the equality. The social and economic inequality growth was estimated as misfortune and injustice of the disadvantaged people. The policy of the laissez-faire of the XIX century interfered the change of provision of the lower class of civil society. Its negative consequences and popularity of democratic criticism of its bases (Russo, Marxism) prepared the spiritual environment of the constitutional state social reforms which ended in the XX century. The previous (social security in Germany XIX century) and the next (social security in the former USSR) experience (Volgin N. A., Gritsenko N. N., Sharkov F.I., 2003, p. 38).

The social constitutional state necessity was caused by the destruction of traditional collective help. With the European industrialization development the relations of freedom of hiring finally replaced the corporate system of the shop relations. The formal equality before the law and freedom of the treaty meant the deprivation of means of production for the mass of workers. If for the businessman the main interest was represented by the maximal profit, for the hired workers - the salary growth as the only source for existence and possibility of creation of a family. Industrialization destroyed the traditional social groups (estates, guilds, rural communities, patriarchal families) and the traditional types of collective help. The visible growth of richness of the bourgeoisie was followed by so visible impoverishment and symptoms of spiritual and moral decline of workers (illness, insanitary conditions of city life, crime, mass alcoholism).

The absence of the labor law regulating the conditions of wage labor led to the poverty growth of population and, as a result, emergence in the XIX century of the organized labor movement headed by the labor unions and social democrats. The fight for the labor law, which has ended only in the XX century, had violence from workers and more from the administration which used the police and army forces for suppression of the opponent. History saved a sample of the treatment of the striking workers: the executions of the Lyons and German weavers in 1930-1940, the Chicago workers in 1886, the Russian workers of the Lenian mines in 1912. The use of lock-outs, strike-breakers, "blacklists" and indicative trials against the trade-unions leaders represents an additional arsenal of traditional business approach to workers' requirements (Chernilovsky Z.M., 1996, p. 540).

The social deprivations of civil society members caused the economic crises in 1873-1878, 1883-1885, 1893-1897, 1908-1909, 1913-1914. The great depression of 1929-1939 has found views inaccuracy of the liberal economists believing in market economy ability to restore the equilibrium functioning by the internal resources (Mamut L.S., 2001; Gritsenko N. N., 1994). The depression actualized the public need for the state interventionism in economics for mitigation of the crisis phenomena. It was becoming more and more obvious that the market competition generates the monopolies which cause damage to public interests and irrational distribution of resources, promote an inequality in incomes and pose a threat to the democratic constitutional state. The need for the antitrust law and the state policy of income redistribution was necessary (Makkonnel K.R., Brus S. L., 1992, p. 293).

The movement for the social state was initiated by the social democrats. The labor unions were close to them according to the economic requirements. The Marxist criticism of the capitalist system radicalized a part of the social democracy: the capitalist reality is not reformed, it is possible only "to soften its patrimonial torments" by the revolutionary denial of the bourgeois state (Marx K., 1955, p. 28). In the western countries the Marxist prophecies mainly were not confirmed because the institutionalization of political freedoms promoted the integration of the left movements into the democratic system of society. Left-wing parties from the marginal turned into the parliamentary parties. They affected in a decisive way the perception of idea of the social state by the liberal and democratic movement (Lyubashits V. Ya., Mordovtsev A.Yu., Mamychev A.Yu., 2013).

The requirements for social protection of the individuals and groups that take structurally weak positions at the economic market, in the democratic constitutional states were gradually becoming common. From the middle of the XIX century and within the $X X$ century the new understanding of human rights due to definition of the social rights was approved (Lyubashits V.Ya., Mordovtsev A.Yu., Mamychev A.Yu. Vronskaya M.V., 2015). The French revolution of 1848 was an example of expansion of these rights. Except the right for a strike and guarantees against different kinds of discrimination, able-bodied persons were got the right for work that obliged the state to pursue full employment policy. The second group of the rights connected with the national economics included the right of hired workers to participate in adoption of the administrative decisions mentioning conditions of wage labor, and the right for these workers to share assignment of profit. The third group of the rights treated non- economic activity: the right to rest and to get the paid holiday, to the aid in case of disasters, the right for vocational education, availability of culture (Omelchenko O. A., 2000, p. 159). 
It is obvious that the traditional economic and democratic rights institutionalized by the French Declaration of human rights and the citizen of 1789 did not completely coincide with the new social rights. The traditional rights demanded only the observance whereas the new rights demanded positively expressed action of the state (Lyubashits V.Ya., Mordovtsev A.Yu., Polyakova A.S., Buharina M.K., 2015).

Therefore, the spiritual prerequisites of development by the constitutional state of the social function were the enlightenment idea of the human right for worthy life in this world (Parsons T., 1954), the criticism of the state policy of the laissez-faire and experience of social security in the authoritative states. The destruction by industrialization of traditional collective help and the impoverishment of hired workers in the crisis economics conditions, the growth of organized labor movement under the direction of Social Democratic Parties and the labor unions, the requirements of supporters of the social state perception by the liberal and democratic movements and the governments refer to the treat conditions of emergence of the social constitutional state.

In the process of experience accumulation of the implementation of social and socially oriented economic policy the social human rights were institutionalized by the constitutions of the constitutional states of the world (Geddes A., Favell A., 1999). This process was accelerated after the adoption of the Universal declaration of human rights of the UN in 1948. For the first time in the history of mankind and the international relations the circle of the main civil, economic, political and social human rights was proclaimed. In spite of the fact that the Universal declaration of human rights is not the international treaty, it according to the custom has got the obligatory force and is the humanistic criterion of the state policy. Democratic Russia which became on the way of creation of the constitutional state affirmed the rights and freedoms of the person and the citizen in the Constitution of the Russian Federation 1993.

The Universal Declaration of Human Rights (p. 23-27) allows to define the social policy principles of the constitutional state in the public system with the market economics. The legal system is urged to provide equality of all citizens before the law. It allows a private property, possession of the economic power. As a result in practice there is the income, property and status inequality. The participants of the economic turn have incomes which define their by the role and the market conditions (Geddes A., 1984). The legitimatizing moral principles are private providing, private responsibility and solidarity (Ovchinnikov A.I., Mamychev A.Yu., Mamycheva D.I. 2015). According to solidarity the one who does not participate in the economic process, receives the compensating benefit. The social security is carried out mainly in the form of an allowance which the individual can use in his own way. The requirements which cannot be financed by the individual are satisfied with the state and public organizations which incur expenses. Therefore, the principles of social policy are: state (public) help (it is financed from taxes and charity foundations), the individual self-help (insurance grants), provision of pensions (the result of the state policy, it is financed from taxes).

\section{Methodology and Materials}

In the course of research of the declared in the article problem the general scientific methods of knowledge were used: the analysis, synthesis, comparison, analogy, deduction, induction, abstraction. Besides, during the consideration of essence and meaning evolution of the social constitutional state such methods, as functional and structural and comparative and legal, and also the legal processes forming, a methodological potential of a modern hermeneutics and phenomenology were used. It is necessary to notice that the principles of the system analysis used for solution of the problem of genesis and evolution of the social state as political and legal institute of society are the basis of the present research. To the principles of the system analysis of the social state evolution refer:

- the principle of public conditionality of genesis and evolution of the social state consisting in the solution of the adaptation problems of society demanding new administrative resources;

- the structurally functional principle focusing on studying of structural components differentiation of the social state and their standard integration allowing to carry out innovative state functions;

- exogenous and endogenous approach within which the intrasocial reasons of emergence of the social state are investigated;

- the historical approach focusing on studying of formation processes, distribution and consequences of the social state.

\section{Results and Discussions}

The concept "the social state" began to be published in constitutions of the constitutional states after the World War II, in particular, in the Basic Law of the Federal Germany 1949 and then in other countries. According to $\mathrm{H}$. Laufer, the institutionalization of this concept proves to be correct by the moral standard of solidarity: "Justice and equality are 
carried out by means of solidarity when the citizens execute a Christian precept "one bears burden of another" and practice it in daily life, help others, take care about weak, forgotten and by that balance mutual interests" (Laufer $H_{\text {., }}$ 1988 , p. 30). The standard of solidarity found an embodiment in the principle of the social constitutional state, meaning intervention of the state in private life of citizens for their worthy life. The principle of the social constitutional state does not exclude, and supplements the democratic constitutionalism of the constitutional state demanding observance of the economic and democratic rights and freedoms of citizens. In the comments of the Constitutional Court of Germany it is said that without implementation of social human rights the realization of its democratic rights is impossible (Laufer $\mathrm{H}$., 1988, p. 32). Nevertheless, between the classical liberal principle of the constitutional state and the principle of the social constitutional state there is a contradiction. In the first case from the state the observance of human rights is expected, whereas in the second - the positive intervention in the private sphere.

There is a question, whether it is possible to consider the social constitutional state as the liberal institute. If to understand the term "the social liberalism" in narrow sense, then it is necessary to identify it with bourgeois liberalism which opposes the state intervention in economics. This understanding of liberalism does not consider historicity of this movement. Liberalism contradictory refers to the state intervention in the private sphere of citizens. Bourgeois liberalism estimated and continues to estimate this intervention as anti-liberal action. At the same time from the moment of the social legislation implementation the liberal democrats supported limited state help, justified it with the private initiative (which has to be socially protected) and the old idea of responsibility of the individual for the living standards. This way of thinking remained up to now. It is focused on economic thrift (Ford H.L., 1988, p. 14). Compulsory social insurance (for example, in Bismarck's Germany) contradicted the spirit of liberalism in that measure, in what primary purpose of these measures there was an equality of income, but not the opportunities.

The current increase of the state responsibility in the social and economic sphere testifies about the transformation of liberalism which rethought the former principle of non-interference. Therefore evolutionary transition to the social constitutional state can be considered as the process of transformation of the liberal movement. So we designate the economic and social policy development by the state creating possibilities of worthy life for greater number of people. The transition to the constitutional social state had spiritual prerequisites and was caused by the economic and socio-political reasons (Lyubashits V. Ya., 1998).

The social policy of the state providing the social rights of citizens depends on resources of the state, economic development of the country and economic policy having social orientation. Unlike the social policy, the economic policy is directed on functioning of all economic system. Its object is social- oriented, but not non- oficial. It corresponds to public needs for growth of the living standards of population forming civil society, its social groups. The purpose of the economic policy is to ensure perhaps more full employment of the population, redistribution of income, reduction of the decline period in production. The economic policy has cyclic character as it is aimed to equilibrium development of the economic system. The economy may undergo the structural changes and cyclic fluctuations. Therefore, to be effective, the economic policy has to be elastic, consider ability of businessmen to adapt for changes of market economy and ability of hired workers to mobility in the sphere of employment (Gritsenko N. N., 1988, p. 18).

It is necessary to distinguish the concepts "the policy of the social constitutional state", its "social" and "economic policy". The first concept is wider and covers the two second concepts. The policy of the social state provides the conditions for realization of the human right for worthy life by means of social protection of the individual (the social policy) and the living standards population growth, social groups of civil society (the economic policy). Between the requirement of the social policy continuity and flexibility of the cyclic economic policy of the constitutional state there is a contradiction. If problems of cyclic policy can't be solved by economic measures, then the social sphere becomes an additional tool of the economic policy in the form of reduction of social programs and reduction of the size of grants. Optimal permission of a contradiction consists in a compromise between the social and economic policy, but not by means state help. Otherwise the population groups will be below the poverty line.

Unlike the social policy, the socially oriented economic policy has a starting point not on taking care of the individual, but on public need for means of activity. The principles of the economic policy are the state minimization of negative consequences of a business cycle and more uniform distribution of the income between social groups of civil society. The policy of the state interventionism at the market economics corresponds to the first principle. The distributive policy corresponds to the second principle. The states pursuing this policy are called sometimes "the states of general prosperity". In the theoretical plan the concept of the state prosperity incorporates the concept of J. Keynes who proved need of the active intervention of the state at the market economics (Makkonnel K.R., Bruce S. L., 1992, p. 301).

The policy of the economic interventionism (that is called also the structural policy) is directed on protection from the negative market consequences of population groups, economic sectors or goods. The restriction of market forces, competition is a policy method. Substitution market functions to the state functions goes on condition of preservation of 
investment ability of private enterprises. The economic growth loses internal dynamics if the economy will be ruled by the government. Therefore the state applies an indirect form of boundary conditions of enterprise decisions regulation and the reactive strategy form for prevention or compensation of collateral influences. Investment strategy of restrictions of economic crises gained distribution. The crisis tendencies are not only softened, but also displaced in the management system of the state. Here they get conflict forms (between the tactical and infrastructure policy, the growth of the state debt), and then the problems move to economics when it was out of crisis. As the figure of efficiency of policy of interventionism decrease in the state debt (Rayzberg B. A. serves., Fatkhutdinov R. A., 1999, p. 734).

The distributive (compensating) economic policy of the constitutional state aims at alignment of economic activity and responsibility conditions. The legislation, taxes, subsidies are its tools. Its necessity is caused by absence in reality of the perfect economic markets, existence of discrimination, restrictions of labor mobility, change of priorities and technological innovations. As the compensating policy mainly has social and economic character, relative alignment of the income between the upper and lower class is accepted to the figure of its efficiency (Rayzberg B. A., Fatkhutdinov R. A., 1999, p. 750).

There is an interrelation between the social and economic policy of the constitutional state. By measures of the structural and distributive policy the state seeks to eliminate unemployment and to raise the living standards of the lower class. If it does not work well, then the needing people are given financial support in a grant form. These payments allow to keep the minimal standard of consumption and to maintain cumulative demand which in turn defines employment. The problem of social security is not settled by the lower bound of social help. Its development is defined by the upper bound, social investments in spheres of health care, education, professional development and professional retraining. Social investments create equality of vital opportunities of members of civil society.

So, the social constitutional state activity is directed to creation of the conditions allowing to realize the right for worthy life to greater number of citizens. Social function of the constitutional state is carried out by means of the social and socially oriented economic policy. Historically the social constitutional state arises in the XX century under the influence of humanistic idea of a human right on worthy life, in the conditions of industrialization and destruction of traditional forms of collective help, crisis economy and perception the liberal and democratic movements and the governments of requirements of supporters of the social state and experience of social security in the countries with authoritarian regime.

The current functioning of the social constitutional state means overcoming of rigid opposition of private and public law. Originally constitutional state was understood as the institute connected by the right in which accurate distinction between the public and private public relations was carried out. It was considered that public action is subordinated to norm of administrative law, and private action - to norm of private law and control of court of law. In the conditions of social and economic intervention of the constitutional state in the sphere of civil society this distinction was outdated. Disappearance of strict distinctions between the public and private law was promoted by development of the state, commercial and industrial service, emergence of the private and public corporations, participation of the state in distribution of the benefits, environmental protection, nationalization of the key branches of economics, and also banking and insurance. All this activity of the constitutional state gained character of public services and began to be regulated by the public law.

With the social function the constitutional state development has become an extremely difficult political association. Its purpose is to ensure the conditions of realization and guarantees of economic, political and social human rights and increase of the living standards of civil society. Its organizational principles include the rule of law, sovereignty of the people, rule of the constitution, division of the authorities, independence of court, a priority of norms of international law over rules of law of the national state. The constitutional state ceased to justify the programs with ideology of classical liberalism, it borrows the argument from different spiritual sources. Fundamental human rights and the citizen structure activity of the state, are humanistic criterion its policy, means of self-realization of members of civil society and a factor of democracy stability. Unlike the non-democratic states, in the constitutional state the institutionalization of the social conflicts is not only effective, but also humanistic.

\section{Conclusions}

There are four innovative stages in the legal institutionalization of the modern political domination: the civil state, the constitutional state, the democratic constitutional state and the social constitutional state. Transition from discretionary to the constitutional state is mediated by the civil state for which the institutionalization of commercial business and the public administration regulation are typical. In the civil state in the era of absolutism there was the transformation of class society to the civil with the characteristic division into the private and public law. Transition to the constitutional state 
which is carried out for the first time in the western countries in the XVIII century was under the influence of the liberal revolutionary movement and is followed by the constitutional endorsement of the government which was earlier limited to bureaucratic means. Emergence in the XIX century the democratic constitutional state was caused by the democratic movement against bourgeois and liberal policy of the electoral right and the laissez-faire restriction, ignoring of the wage labor conditions. The social function development by the democratic constitutional state was going within the XX century. The social state guarantees the members of civil society freedom from the poverty and worthy life, social protection policy, distributive and structural economic policy denying the strict division into the private and public law.

\section{References}

Volgin N.A., Gritsenko N.N., Sharkov F.I. (2003) Social'noe gosudarstvo. M.( The social state)

Gritsenko N.N. (1994) Social'nomu gosudarstvu - jeffektivnuju social'nuju politiku //Materialy kongressa «Chelovek: social'naja politika v period osushhestvleniya ekonomicheskikh reform». M. P. 8-14.

Gritsenko N.N. (1988) Social'noe gosudarstvo (social'no-ekonomichesky aspekt) // Ekonomicheskaya rol' gosudarstva v perehodnoi ekonomike. Chelyabinsk. P. 3-18.

Kamenetsky V.A., Patrikeev V.P. (2001) Lektsii po ekonomike. Problemy stanovleniya social'nogo gosudarstva. M.

Kant I. (1966) Sochinenija. V 6 t. M., T.6.

Lyubashits V.Ya., Mordovcev A.Yu., Mamychev A.Yu. (2013) Gosudarstvennaja vlast': paradigma, metodologija, tipologija. M.

Lyubashits V.Ya. (1998) Formirovanie grazhdanskogo obshhestva - vazhneishee uslovie dostizheniya svobody lichnosti //Prava cheloveka v Rossii: vremja nadezhd i razocharovanij. Rostov-on-Don.

Makkonnel K.R., Bryus S.L. (1992) Ekonomiks: principy, problemy i politika. V 2 t. M. T.2.

Mamut L.S. (2001) Social'noe gosudarstvo s tochki zrenija prava // Gosudarstvo i pravo. № 7. P. 5-14.

Marks K. (1955) Kapital. T.1 //Marks K., Jengel's F. Soch. 2-e izd. T.23.

Omel'chenko O.A. (2000) Vseobshhaja istorija gosudarstva i prava. V 2-h T. M., T.2.

Rajzberg B.A., Fathutdinov R.A. (1999) Upravlenie ekonomikoi. M.

Chernilovsky Z.M. (1996) Vseobshhaja istorija gosudarstva i prava. M.

Chernobrovkin I.P. (1997) Social'naja zashhishhennost' //Chelovek i obshhestvo: kratkij enciklopedicheskij slovar'-spravochnik (politologija). Rostov-on-Don.

Ford H.L. (1988) Work, Organization and Power. Introduction to Industrial Sociology. Texas.

Geddes A., Favell A. (1999) The Politics of Belonging: Migrants and Minorities in Contemporary Europe. Aldershot: Ashgate.

Giddens A. (1984) Constitution of Society: Outline of the Theory of Structuration. Berkeley; Los Angeles: University Press

Laufer H. (1988) Der Grundkonsens in der freineitlichen Demokratie. Köln.

Lyubashits V.Ya., Mordovtsev A.Yu., Mamychev A.Yu. Vronskaya M.V. (2015) Typological analysis of evolutionary forms of a state /I Mediterranean Journal of Social Sciences. Vol. 6, № 3, May. Supplement 3.

Lyubashits V.Ya., Mordovtsev A.Yu., Polyakova A.S., Buharina M.K. (2015) Society and the state: the problem of structuring publicdecorated history // Mediterranean Journal of Social Sciences. Vol. 6, № 3, May. Supplement 3.

Mamychev A.Yu., Kiyashko E.Yu., Timofeeva A.A. (2015) Conservative political transformation projects of Russian power: the main discourses of modernity // Mediterranean Journal of Social Sciences. Vol. 6, № 3, May. Supplement 2. P. $389-396$.

Merton R.K. (1957) Social Theory and Social Structure / Robert K. Merton. Enl. Ed. New York: Free press

Mordovtsev A.Yu., Mordovceva T.V., Mamychev A.Yu. (2015) Convergence of law: the variety of discourses // Mediterranean Journal of Social Sciences. Vol. 6, № 3, May 2015. P. $262-268$.

Ovchinnikov A.I., Mamychev A.Yu., Mamycheva D.I. (2015) Socio-cultural foundations of coding state-legal development /I Mediterranean Journal of Social Sciences. Vol. 6. №3.

Parsons T. (1954) Essays in sociological theory. Glencoe, 1954. 